INSTITUTE OF FORESTRY • BELGRADE

INSTITUT ZA ŠUMARSTVO • BEOGRAD

SUSTAINABLE FORESTRY

ODRŽIVO ŠUMARSTVO

COLLECTION 71-72, 2015

ZBORNIK RADOVA 71-72, 2015

UDK 332.3:551.3.053(497.11 Grdelička klisura)“1963/2011“=111

Original scientific paper

\title{
CHANGES IN LAND USE IN THE REGION OF GRDELICA GORGE IN THE PERIOD 1963-2011
}

Sonja BRAUNOVIĆ, Mihailo RATKNIĆ, Tatjana RATKNIĆ, Milan KABILJO ${ }^{l}$

\begin{abstract}
A land use is the sole erosion factor that can be controlled and governed by man. Since an inadequate land use can cause intensification of erosive processes, it is possible to reduce their intensity by its change.

The paper presents the changes in land use in the region of Grdelica Gorge in the period between 1963 and 2011 and the impact of the changes on the intensity of erosive processes. The identification of wooded land, arable land, meadows, pastures, orchards, vineyards and infertile land performed in 2011 was based on field works and the analysis of high resolution satellite images. The comparison of the obtained results with the data for 1963 proved that the categories of barren land, forest, meadow and pasture underwent most intensive changes. The above-mentioned changes, along with performance of biological and technical works, resulted in reduction of intensity of erosive processes in the observed period.
\end{abstract}

Key words: land use, erosive processes, erosion coefficient (Z)

\section{PROMENE NAČINA KORIŠĆENJA ZEMLJIŠTA NA PODRUČJU GRDELIČKE KLISURE U PERIODU 1963-2011}

Način korišćenja zemljišta predstavlja praktično jedini faktor nastanka erozije koji čovek može da kontroliše i da upravlja njime. Pošto neadekvatna upotreba zemljišta izaziva intenziviranje erozivnih procesa, moguće je promenom načina korišćenja zemljišta smanjiti intenzitet razvoja erozije.

\footnotetext{
${ }^{1}$ Institute of Forestry, Belgrade, Serbia. e-mail: sonjabraunovic@yahoo.com

* Acknowledgement The research is financed by the Ministry of Science and Technological Development of the Republic of Serbia, Project TR 31070 "The development of technological procedures in forestry with a view to an optimum forest cover realisation" (2011-2015).
} 
U radu su prikazane promene načina korišćenja zemljišta u regionu Grdeličke klisure u periodu između 1963. i 2011. godine, kao i uticaj nastalih promena na intenzitet erozionih procesa. Kartiranje površina pod šumama, oranicama, livadama, pašnjacima, voćnjacima, vinogradima i neplodnim zemljištem obavljeno je 2011. godine na osnovu terenskih radova $i$ analize satelitskih snimaka visoke rezolucije. Poređenje dobijenih rezultata sa podacima za 1963. godinu pokazalo je da su kategorije goleti, šuma, livada $i$ oranica pretrpele najintenzivnije promene. Gore pomenute promene, zajedno sa izvedenim biološkim i tehničkim radovimaa, rezultirale su smanjenjem intenziteta erozionih procesa $u$ posmatranom periodu.

Ključne reči: način korišćenja zemljišta, erozioni procesi, koeficijent erozije (Z)

\section{INTRODUCTION}

In the mid $20^{\text {th }}$ century, the region of Grdelica Gorge and Vranje Valley represented the epicentre of development of the most intense erosion processes. Devastating torrential streams threatened human lives, motorways and the Belgrade-Skopje-Thessaloniki railway, arable land, etc. The study of changes of intensity of erosive processes provides the insight into the causes of their mitigation, which took place in the period between 1963-2011.

Land use, in addition to analysis of meteorological and climate conditions, relief, geological and pedological layer, the degree of representation of the observed erosion processes, represents one of the key factors in identification and mapping of erosion processes. Through use of land and other natural resources for the purpose of social and economic development, human activities can either disturb and endanger the naturally established balance or preserve it and enhance it. This is the reason why a manner of land use, as a significant anthropogenic erosion factor, is the central focus of this study. The paper presents the change in land use in the region of Grdelica Gorge in the period 1963-2011.

\section{WORK METHOD}

Based on the available topographic maps, field mapping and use of satellite images of the study area, the manner of land use in 2011 was analysed and defined (Braunović, Ratknić, 2010). The structural composition of the area was determined by means of identification of homogenous plots (Image 1). The selection of primarily productive and unproductive areas within the homogenous wholes was performed. The productive areas include forests, degraded forests, meadows and pastures, orchards, house adjacent plots and gardens. The unproductive areas include gullies, stone fields, gravel, road networks, water courses and building land in settlements. According to the above categories, 1,780 homogenous plots were identified in the study area. Based on the above-mentioned systematisation of the study area, a digital map of land use was created and percentage representation of productive and unproductive areas, according to above categories, was calculated. 


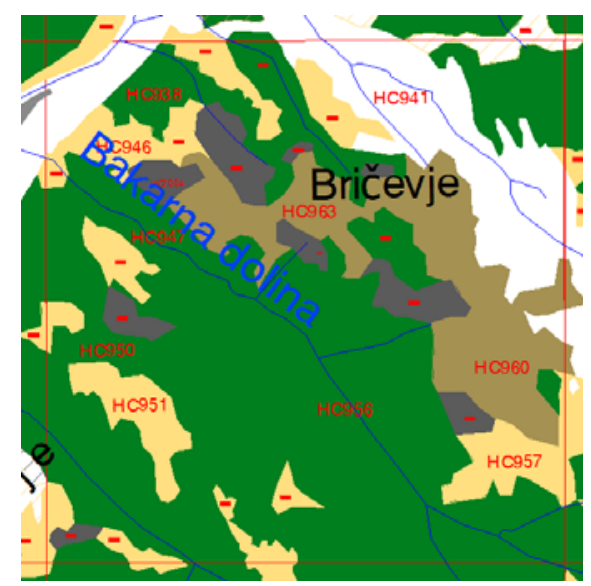

Image 1. A detail of 2011 land use map

\section{RESULTS AND DISCUSSION}

The Grdelica Gorge is situated in the northernmost part of the Južna Morava River catchment basin, in the stretch between Grdelica and Vladičin Han. Its catchment area is bound by mountain massifs: from the east by Mt Čemernik (1,638 and 1,592 metres), Mt Ostrozubska Čuka (1,546 metres), from the northeast by Mt Jastrebac (1,330 metres), from the west by Mt Kukavica (1,404 metres) and Mt Jelova Glava (1,114 metres), while in the south it is open towards the Vranje Valley. In administrative terms, the region of Grdelica Gorge belongs to the municipalities of Grdelica and Vladičin Han, except for a smaller part of the Džepska River catchment basin, which territorially belongs to the municipality of Surdulica.

The total surface area of the river catchment basin is $430.44 \mathrm{~km}^{2}$, out of which $427.61 \mathrm{~km}^{2}$ are torrential catchments, while $2.83 \mathrm{~km}^{2}$, out of torrential catchment, are situated in the inner area of towns Vladičin Han and Surdulica. The area is of an asymmetrical shape, as the right side is more developed (Image 2).

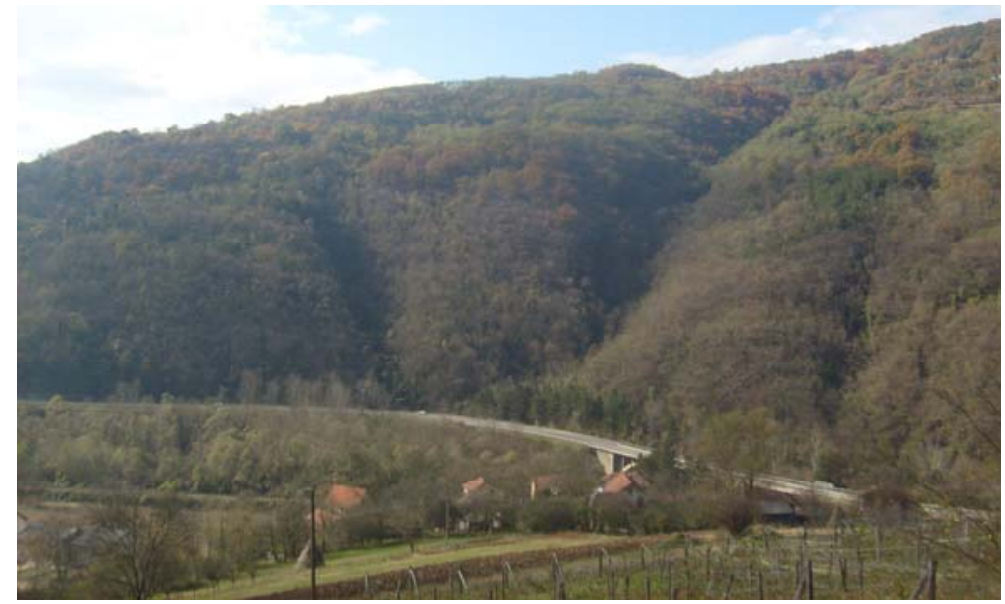

Image 2. Grdelica Gorge-Zla Dolina River catchment basin, Photo: Braunović, S., 2011 
The right tributaries of the Južna Morava River, in the section from Grdelica to Vladičin Han (the Sejanička, Predejanska, Krpejska and Džepska River), run through so-called 'green schists', composed of different types of brittle schists (chlorite, serecite and other), which are very susceptible to the impact of water. Most of the springs of the above rivers are linked to outflow contact of dacitic rocks with schists. For that reason, these torrent streams have precipitous upper sections, since dacites are hard rocks. In some places, where dacite outflows are located in the lower stream, as it is the case with the Džepska River, this stream section also has steep sides (Braunović et al., 2010). The left tributaries of the Južna Morava River (the Letoviška River, Bistrica, Lepenica, Repiška, Kalimanska) are in most parts of their streams cut into granite gneisses and gnaisses, which results in significant descents of their river beds. Their springs are mainly linked to the contact of granite-gneisses with granites and andesites, where impenetrable hardness of rocks causes increased descents. The lower sections of these torrent streams are cut into neogene non-resistant sediments and have mild descents. The hydrographic and topographic characteristics of Grdelica Gorge are presented in the Table 1.

Table 1. Hydrographic and topographic characteristics

\begin{tabular}{|l|c|r|}
\hline \multicolumn{1}{|c|}{ Parameter } & Designation & $\begin{array}{c}\text { Grdelica } \\
\text { Gorge }\end{array}$ \\
\hline Surface area of the catchment basin & $\mathrm{F}\left(\mathrm{km}^{2}\right)$ & 430.44 \\
\hline Circumference of the catchment basin & $\mathrm{O}(\mathrm{km})$ & 99.57 \\
\hline Length of the main stream & $\mathrm{L}(\mathrm{km})$ & 29.50 \\
\hline The most upstream elevation point of the main stream & $\mathrm{K}_{\mathrm{v}}(\mathrm{metres})$ & 324.00 \\
\hline The most downstream elevation point of the main stream & $\mathrm{K}_{\mathrm{u}}($ metres $)$ & 253.00 \\
\hline Stream winding coefficient & $\mathrm{K}_{\mathrm{k}}$ & 0.69 \\
\hline Number of torrential tributaries & & 137 \\
\hline Average descent at the section & $\mathrm{I}_{\mathrm{p}}(\%)$ & 2.41 \\
\hline The total length of hydrographic network & $\Sigma \mathrm{L}(\mathrm{km})$ & 277.01 \\
\hline The density of hydrographic network & $\mathrm{G}(\mathrm{km} \cdot \mathrm{km})$ & 0.64 \\
\hline The mean width of the area & $\mathrm{S}_{\check{\mathrm{s}}}(\mathrm{km})$ & 14.59 \\
\hline Catchment basin's coefficient of asymmetry & $\mathrm{a}$ & 0.82 \\
\hline Shape coefficient of the catchment basin & $\mathrm{A}$ & 0.54 \\
\hline Highest elevation spot of the catchment basin & $(\mathrm{metres})$ & 1638.00 \\
\hline Mean altitude of the catchment basin & $\mathrm{N}_{\mathrm{sr}}(\mathrm{metres})$ & 789.57 \\
\hline Mean altitude difference of the catchment basin & $\mathrm{D}(\mathrm{m})$ & 536.57 \\
\hline
\end{tabular}

The average descents of torrential tributaries are large and range between 6-38\%. All tributaries in this catchment basin have typical torrential characteristics: a developed spring area, large descents in upper and middle streams, $1-3 \%$ descents in lower streams, strongly pronounced or strongly developed river deposits (Table 2). 
Table 2. Hydrographic and orographic characteristics of large tributaries of the Južna Morava River in Grdelica Gorge

\begin{tabular}{|c|c|c|c|c|c|c|c|}
\hline Name of catchment basin & $\begin{array}{c}\mathrm{F} \\
\left(\mathrm{km}^{2}\right)\end{array}$ & Shape of catchment basin & Flow direction & $\begin{array}{c}\mathrm{L} \\
(\mathrm{km})\end{array}$ & $\begin{array}{c}\mathrm{S}_{\check{s}} \\
(\mathrm{~km})\end{array}$ & $\begin{array}{l}\Delta \mathrm{h} \\
(\mathrm{m})\end{array}$ & $\begin{array}{c}\text { Stream descent } \\
(\%)\end{array}$ \\
\hline \multicolumn{8}{|c|}{ LEFT TRIBUTARIES } \\
\hline Kozarska River & 101.0 & Elongated & SE-NW & 3.15 & 3.63 & 1190 & 37.78 \\
\hline Bistrička River & 29.18 & Elongated & SE-N & 9.20 & 3.00 & 680 & 7.39 \\
\hline Jastrebačka River & 9.84 & Elongated & NW-SE & 4.68 & 1.92 & 500 & 10.68 \\
\hline Letoviška River & \begin{tabular}{|c|}
19.60 \\
\end{tabular} & Elongated & NW-SE & 8.40 & 2.26 & 680 & 8.10 \\
\hline Rdovska River & 19.36 & Elongated & NW-SE & 10.75 & 1.76 & 980 & 9.12 \\
\hline \multicolumn{8}{|c|}{ RIGHT TRIBUTARIES } \\
\hline Palojska River & 6.87 & Elongated & NE-SW & 4.60 & 1.52 & 480 & 10.43 \\
\hline Predejanska River & \begin{tabular}{|l|}
19.58 \\
\end{tabular} & Fanlike & E-W & 7.45 & 2.68 & 620 & 8.32 \\
\hline Džepska River & \begin{tabular}{|c|}
91.88 \\
\end{tabular} & Fanlike & E-W & 20.40 & 4.50 & 1200 & 5.88 \\
\hline Koznica & 21.57 & Elongated & E-NW & 11.50 & 1.83 & 680 & 5.91 \\
\hline
\end{tabular}

Source: General Plan for Management of Grdelica Gorge and Vranje Valley

A: Natural conditions and relief, 1956

Data on land use for 1963 were calculated based on the available data from 'List of torrent streams of right and left tributaries of the South Morava River in the stretch Grdelica - Vladičin Han, Register of torrential catchments and descents', prepared by the Regional section for protection of soil against erosion and torrent stream regulation, Vladičin Han, 1964. By the synthesis of the above-mentioned data, it was established that forests accounted for $33.19 \%$, ploughed land $32.80 \%$, meadows and pastures $7.39 \%$, orchards $1.46 \%$, house adjacent plots and gardens $0.43 \%$ of the total catchment basin's surface area, that is, the productive areas constituted $75.27 \%$ of the study area's total surface area. In 1963, barren land accounted for $22.38 \%$ of the catchment basin, that is, over $1 / 5$ of the study area.

When the share of the areas encompassed by the term 'non-catchment areas' (built up areas, asphalted roads and watersheds) is added to the share of barren land, it can be concluded that non-productive areas occupied $24.73 \%$, or one quarter of the total Grdelica Gorge surface area (Table 3).

Table 3. Land use in Grdelica Gorge (1963)

\begin{tabular}{|c|c|c|}
\hline Category & $\begin{array}{c}\text { Surface area } \\
\text { ha }\end{array}$ & $\begin{array}{c}\text { Share } \\
\%\end{array}$ \\
\hline Forests & 14286.30 & 33.19 \\
\hline Meadows and pastures & 3180.95 & 7.39 \\
\hline Ploughed land & 14118.43 & 32.80 \\
\hline Orchards & 628.44 & 1.46 \\
\hline House adjacent plots and gardens & 185.09 & 0.43 \\
\hline Productive areas & 32399.22 & 75.27 \\
\hline Barren land & 9633.25 & 22.38 \\
\hline Non-catchment areas ${ }^{2}$ & 1011.53 & 2.35 \\
\hline Non-productive areas & 10644.78 & 24.73 \\
\hline Total & 43044.00 & 100.00 \\
\hline
\end{tabular}

Source: List of torrential streams of right and left tributaries of the Južna Morava River in the stretch Grdelica - Vladičin Han, 1964

\footnotetext{
${ }^{2}$ Built-up areas, asphalted roads, water courses
} 
Table 4. Land use in Grdelica Gorge (2011)

\begin{tabular}{|l|r|r|}
\hline \multicolumn{1}{|c|}{ Category } & $\begin{array}{c}\text { Surface area } \\
\text { ha }\end{array}$ & \multicolumn{1}{c|}{$\begin{array}{c}\text { Share } \\
\%\end{array}$} \\
\hline Forests Forests & 23526.18 & \multicolumn{1}{c|}{99.43} \\
\hline Degraded forests & 134.36 & 0.57 \\
\hline \multicolumn{1}{|c|}{ Meadows and pastures } & 10772.61 & 100.00 \\
\hline Degraded pastures & - & - \\
\hline High mountain meadows and pastures & - & - \\
\hline Meadows and pastures & 10772.6 & 25.03 \\
\hline Ploughed land & 2727.59 & 6.34 \\
\hline Vineyards & 68.26 & 0.16 \\
\hline Orchards & 127.75 & 0.30 \\
\hline House adjacent plots and gardens & 1296.97 & 3.01 \\
\hline Productive areas & 4220.57 & 89.80 \\
\hline Settlements (construction zone) & 698.37 & 1.62 \\
\hline Gullies & - & - \\
\hline Stone fields & 23.79 & 0.06 \\
\hline Gravel & 81.96 & 0.19 \\
\hline Road network and water courses & 3586.16 & 8.33 \\
\hline Non productive areas & 4390.28 & 10.20 \\
\hline Total & 43044.00 & 100.00 \\
\hline
\end{tabular}

Source: Braunović, S (2013)

In 2011, the productive areas in the region of Grdelica Gorge constituted $89.8 \%$ of the study area's total surface area (Table 4). Within productive areas, forests covered $55 \%$ of the total surface area. Degraded forests, mainly oak stands, most frequently in the proximity of settlements, were also identified. Meadows and pastures covered $25 \%$ of the total area, out of which $5 \%$ were occupied by degraded pastures and $9 \%$ by high-mountain meadows and pastures. Ploughed land occupied $21 \%$ of the productive area, stretching along the valley of Južna Morava River and the lower streams of its large tributaries. Very small stretches of ploughed land are situated on higher altitudes and high-inclination slopes. Nonproductive areas covered $10.2 \%$ of the total area. The highest percentage of these areas consist of road networks and water courses, followed by building land, stone fields and gullies.

In the period between 1963 and 2011, a significant decrease of ploughed land $(28 \%$ of the productive area) took place in the studied area. The share of ploughed land in the total surface area dropped, that is, ploughed land was abandoned and naturally 'transferred' into the category meadows and pastures, the share of which increased by $18 \%$. A $13.4 \%$ increase of afforested areas was identified in comparison to 1953 , resulting in $45 \%$ afforestation percentage in 2011. In comparison to 1963 , non-productive areas decreased by nearly $15 \%$.

From the aspect of development of erosion processes, the changes in land use that took place in the observed period, contributed to their stabilisation. The value of the mean erosion coefficient in the region of Grdelica Gorge, calculated by means of use of the Prof Gavrilović's methodology (Gavrilović, 1972), in 1963 amounted to $\mathrm{Zsr}=0.67$ (moderate erosion processes), whereas in 2011 it was reduced to $\mathrm{Zsr}=0.34$ (low erosion processes). 


\section{CONCLUSION}

Based on a map of manner of land use, created in 2011, it was established that the productive area constitutes $89.8 \%$, whereas the non-productive area accounts for $10.2 \%$ of the total surface area of Grdelica Gorge. In addition to its primary purpose, the created map of manner of land use, was used as the basis for drawing up of an erosion map of the studied area.

The comparison of the obtained results with the results obtained in 1963, indicated that the most significant changes in manner of land use took place within the categories of barren land, forests, meadows and pastures. A decrease of barren land, ploughed land, meadows and pastures occurred as a result of rehabilitation, performed in the $1960 \mathrm{~s}$, of areas affected by intensive erosion processes (performance of technical works in river beds and bio-technical and biological works on catchment slopes).

Another reason for these changes is the migration from high-hilly areas to urban centres, which resulted in abandonment of agricultural areas, which were spontaneously covered by vegetation over the time. The changes in manner of land use in the observed period, in addition to other factors, had an impact on reduction of intensity of erosion processes. In 1963, the mean erosion coefficient in the region of Grdelica Gorge was $\mathrm{Zsr}=0.67$, whereas in $2011 \mathrm{Zsr}=0.34$, which means that moderate erosion processes were reduced to the category of low erosion processes.

\section{REFERENCES}

1. Braunović S., Ratknić M., Rakonjac Lj.: (2010): The site characteristics of the Grdelicka gorge and vranjska basin areas. International Scientific Conference "FOREST ECOSYSTEMS AND CLIMATE CHANGES". Institute of forestry, Belgrade Proceedings pp. 91-96

2. Braunović S., Ratknić M. (2010): The creation of the erosion map by the use of the satellite photos of high resolution for Krpejski potok drainage area. International Scientific Conference "FOREST ECOSYSTEMS AND CLIMATE CHANGES". Institute of forestry, Belgrade Proceedings pp. 251-256

3. Braunović S. (2013): Efekti protiverozionih radova na stanje erozije u Grdeličkoj klisuri i Vranjskoj kotlini“'. Doktorska disertacija, Šumarski fakultet Beograd

4. „Popis bujica desnih i levih pritoka Južne Morave na deonici Grdelica - Vladičin Han. II Registar bujičnih slivova i padina“. Reonska sekcija za zaštitu zemljišta od erozije i uređenje bujica Vladičin Han 1964. godine.

5. Gavrilović, S. (1972): Inženjering o bujičnim tokovima i eroziji (Engineering of torrents and erosion) (in Serbian). Izgradnja, Belgrade special edition.

6. (2008) II Generalni projekat protiverozionog uređenja bujičnih tokova na području Grdeličke klisure. Šumarski fakultet i Institut za vodoprivredu „Jaroslav Černi“, Beograd 


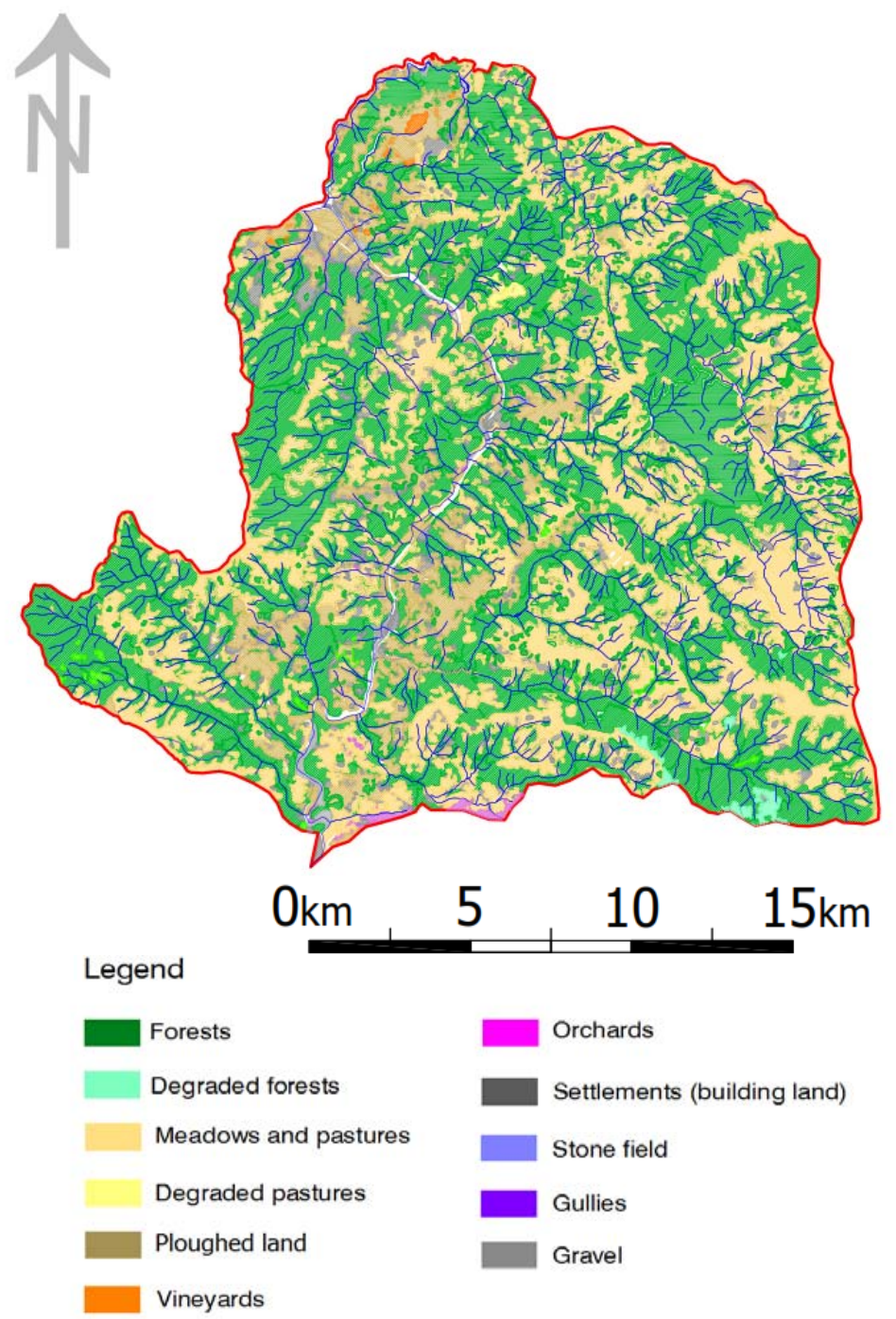

Image 3. A map of manner of land use - Grdelica Gorge 2011 